\section{Det litterære rum}

FREDERIK TYgSTRUP

Litteraturteorien har gerne lagt mere vægt på litteraturens tid end på litteraturens rum. Det mest betydningsfulde litteraturteoretiske værk nogensinde, Aristoteles' poetik, satte fortælleteorien - undersøgelsen af begivenhedernes komposition $i$ et forløb på den centrale plads, og der har den stort set stået uantastet lige siden. Den intense fokusering på den narrative forms struktur, logik og dynamik har betydet, at spørgsmålet om litterær komposition først og fremmest er blevet betragtet som et sporosmå om succession om de feensillede begiventoma ofter-bisibn $i$ de frementers end et spørgsmål om situation, begivenhedenes placering $i$ et rum og sammenhæng med dette rum.

Denne tendens har fảet en markant formulering Lessings lille afhandling Laokoon fra 1766 , hvor han foreslår en slags æstetisk Jalta, der på god aristotelisk vis lader litteraturen fremstille det, som er "nacheinander in der Zeit", og den bildende kunst tilsvarende det, som er "nebeneinander im Raume“" Der er noget bestikkende og indlysende rigtigt ved denne distinktion, omend den også, så indlysende den er, kan komme til at slore nogle af de problemer, der vedrører litteraturens forhold til tid os rum. Jeg vil her hæfte mig ved tre problemer. Fo det forste er der grund til at precisere, at de to the det forse er der gard al ar prace de og det bildende kunstværks ved-siden-af-hinanden - forst og fencer organisationsprincipper i sproget og billedet, ikke faktiske tidslige og rumlige forhold. Tid og rum må her snarest opfattes som metaforer for det sproglige mediums forløbskarakter og billedmediets organisation af samtidige, synlige elementer. I forlængelse heraf må man uden tvivl spørge, om der ikke også er formelle træk i den litterære tekst, der tilsvarende kunne me- taforiseres som rumlige, hvor teksten har karakter af et nebeneinander. For det andet gentager Lessing overensstemmelse med god symmetrisk skik denne formelle distinktion på det stoflige område, således at litteraturens og billedkunstens foretrulene genstande bliver henholdsvis tidslige og rumlige fænomener. Hvordan denne symmetri skal begrundes, berører han imidlertid ikke, ${ }^{\mathrm{I}}$ og formentlig er der en mere kompliceret vekselvirkning mellem de to sider, således at "formelt" rumlige træk $i$ en tekst kan fremstille tidslige forhold, og tilsvarende ,formelt“ tids lige tidslige for tidslige trelk man for det trede ben ring af temporelle forhold, der kendetegner Lessings afhandling. Ikke nok med at han investerer digtningens og hele sprogets kraft og betydning $i$ en udfoldelse af det tidslige; det viser sig også, at han selv på billedets område fordrer, at den billedlige fremstilling bør fastholde et kritisk øjeblik, enten lige for eller efter en begivenheds kulmination. Når Lessing så at sige giver tiden hvad tidens er og rummet hvad rummets er, er det samtidig med udgangspunkt i en antagelse af, at det er tiden, som er den afgørende interessante dimension, hvormed han, åndshistorisk betragtet, forbereder den voldsomme interesse for of og tematisering af tiden, der kendetegner det nit-

Jeg vil i det følgende tage disse tre problemkomplekser op, for resten uden særlig hensyntagen til Lessing i øvrigt, og diskutere, om der kan findes rumlige formtræk $i$ den litterære tekst, om litteraturen $i$ forlængelse heraf kan betragtes som et medium til at fremstille rummet, og om denne interesse fo fremstillingen af rummet selv er indskrevet $i$ en anden vægtning af forholdet mellem tid og rum en den, der kommer til udtryk hos Lessing. Min hypo- tese vil være, at den litterære tekst som medie har en rumlig dimension, og at den herigennem er stand til at fremstille rumlige forhold på måder, som adskiller den fra andre medier. I teksten eksisterer der et netværk af relationer, både formelt mellem de lingristiske forlte mellem femantisk, me lem de implicit eller eksplicit fremstillede elementer. De semantiske relationer træder frem gennem be skrivelser, gennem narrative forløb, gennem fremstilling af mentale processer, sansninger, affekter og associationer, og gennem de umiddelbare betydningsmæssige nærhedsrelationer og tværforbindelser, der etableres i teksten. Disse relationer er i en tekst som regel organiseret med en vis konsistens, de danner et plan, som modsvarer en mulig anskuels af rummet. Relationernes plan danner et rum-billede, som oscillerer mellem det eksplicitte og det implicitte. Det kan have karakter af repræsentation, men det kan osså danne en imainar struktur, som ikke umiddelbart modvarer en anskuelse, men som skematicer skematiserer ans op oger etler opender en lang række sà at sige sedimenterede organise ringer af rumanskuelsen, som er objektiverede i et komplekst system, der omfatter et vidt spektrum a momenter såsom natursyn, byplan, litterær konvention (det, som Bakhtin kalder "kronotopiske“ strukturer), arkitektur, trafikadfærd, topografi, gestik os Rumanskuelsen er, sådan som ikke mindst Erns Cassirer og Michel Foucault har understreget, indlejret $i$ en historisk orden, et videns- og anskuelsesregime. Denne rumanskuelsens historicitet kan vise sig $i$ arbejdet med det litterære rum på forskellige måder. Litteraturen er en integral del af det historiske vidensregime ved po den ene side at uhistonisk vidtryk en historisk organisering af rumanskuelsen og $\mathrm{p}$ den anden side kom anskuelse, således at den altsa bidrager til at både reproducer og omskabe den historiske anskuelses orden. I de første dimension er litteraturen et vidnesbyrd, en repræsentation af en historisk rumorganisering, men den i det andet er et laboratorium for konstruktio af mulige anskuelser, af fiktive rum. Man kan $\mathrm{p}$ denne baggrund udspecificere en række forskellige indfaldsvinkler til det litterære rum og tilsvarende hermeneutiske problemer. Betragter man forholdet mellem læseren og teksten, bliver det afgørende dialogen mellem læseren, med hendes historiske og erfaringsspecifikke forudsætninger, og tekstens skematiseringer; betragter man det historiske forhold mellem teksten og dens kontekst, bliver fot hold

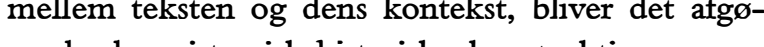
for kunstruktion af rummet, som den deltager i; og betragter man endelig forholdet mellem den litterære skaben og dens forudsætninger, bliver det fremfor alt det strategisk-taktiske felt, hvor den kunstneriske skaben artikulerer sig som en deformation af de epistemiske formninger af anskuelsen, som den historisk intervenerer $\mathrm{i}$, dens kodificering af mulige og aktuelt på en eller anden måde interessante rum.

I. Rummets genkomst

For en historisk betragtning er det ikke til at overse, at netop den situation $\mathrm{i}$ kunsten, som Lessing gør op med midt $i$ det attende århundrede, synes at være den dominerende tendens $i$ det tyvende. Lessings grænsedragning er et opgør med udviklingen af æstetiske blandingsformer, med ut pictura-poetikken på den ene side, som nedprioriterer det episke i litteraturen til fordel for det æstetisk behagelige billede, og mod den allegoriske tendens i malerkunsten på den anden, dvs. mod tendensen til at narrativisere den billedlige fremstilling. Men omvendt er netop blandingsformerne et af de vigtigste kendetegn for det tyvende århundredes kunst. I billedkunsten har der været en intens interesse for at undersøge grænsen mellem skriftlighed og billede, og fra Klee og Magritte frem til vor tids postminimalistiske billedkunst finder  nets men en selvstændig ting, og tingen, der bliver til tegn. Billedet er blevet semiotiseret, tiltagende fokuseret pà spørgsmålet om laselighed, ligesom den konceptuelle kunst og store dele af kontekstkunsten $i$ de seneste
årtier vel $i$ grunden først og fremmest indbyder til en allegorisk læsemåde.

På en tilsvarende måde, og måske endda endnu mere monumentalt, har man på litteraturens område 
kunnet iagttage en „rummets tilbagekomst“ $i$ det tyvende århundredes litteratur. Eller rettere, måske ikke en tilbagekomst, men en synliggrrelse af rummet i det omfang tiden - plottets, den narrative kausalitets tid - syntes at miste den dominerende stilling tets ind $\mathrm{i}$ i det nitende den indlog idet nittende arhundredes romaner som et centematisk centralfigur. En af de forste til at gøre opmærksom på „rummets genkomst" $\mathrm{i}$ litteraturen var den amerikanske kritiker Joseph Frank, der i en berømt artikel fra 1945 med titlen „Spatial Form in Modern Literature" afsøgte en række overvejende rumlige form-træk hos Flaubert, Joyce, Proust og Djuna Barnes. ${ }^{3}$ Franks fortjeneste er ikke mindst at have gjort opmærksom på vanskelighederne ved at anskue værker som disse ud fra et narrativt formskema alene, og på behovet for en grundlæggende kortlægning af spatiale organisationsprincipper i litteraturen overhovedet. For Frank betyder ,spatial form “ således, ligesom hos Lessing, forst og fremmest formelle des, ligem hos greb og principper, som ille kan fores tilbage til narraivt-temporaliserer indbyder til thlive besket end en tidslig metaforik. I denne henseende kan Frank - sammen med den nykritiske tendens $i$ amerikansk litteraturteori, som han kan siges at være en del af - betragtes som en art forløber for den sidenhen dominerende formalisme i litteraturvidenskaben med dens veludviklede sans for tematiske, semantiske og lingvistiske modeller, hvor de litterære formprincipper netop fastholdes i overvejende rumlige modeller. Men for Frank drejede det sig imidlertid ikke alene om at artikulere denne formelle rumlighed, men også om at markere en litteraturog idehistorisk tendens, et ideologisk skif i det tyog idehistonisk ondent vende àrhundredes litteratur til at tilnærme sig en
forståelse af selvet og af verden med udgangspunkt rumlige

Ideen om, at det tyvende århundredes kultur igen synes at sæette spørgsmålet om rummet på dagsordenen, er blevet formuleret på en række forskellige måder. Den tjekkiske filosof Jan Patocka mener at se en overordnet udvikling i rumforestillingen med tre distinkte faser, fra et førmoderne rum, som har udgangspunkt i de konkrete relationer mellem ting, til et moderne rum - med centralperspektivet og den cartesianske dioptrik som markante udtryk - hvor tingene ikke længere skaber rummet, men så at sige er anbragt i et rum og dermed underordnes et rum, som går forud for dem, og så endelig det rum, som synes at vere det dominerende $i$ det tyvende århundrede, hvor perspektivet igen treder $i$ brorunden ren 1 baggrunden summe pa, og hvor det igen biver delatio mellem enkeltfænomener, som udgør rummet. For Patocka er det ikke mindst fænomenologien, med dens fokusering på den konkrete erfaring af verden, der har bidraget til at genfremsætte spørgsmålet om rummet på en måde, som rækker ud over det, der kan besvares geometrisk og matematisk. 5 En anden tænker, som har set rummets genkomst som et centralt problem i det tyvende århundrede, er Michel Foucault. Hans opgør med det nittende århundredes humanvidenskab er eksplicit rettet mod den forestilling om tidslig transcendens, der preger historieforingorister staelsen og antropologien. I stedet for at forstå den

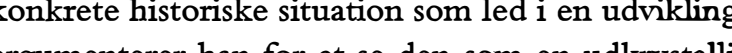
argun sering af bestemte magtforhold, dvs. som placeret en orden snarere end $i$ et forløb; og $i$ stedet for at forstå det menneskelige subjekt som indskrevet $i$ en temporal meningssammenhæng (historisk, eksistentiel), forskyder han interessen til en historisk krop, der er genstand for en bestandig konstruktion unde tryk af de magt- og vidensstrategier, der eksistere omkring den. På denne baggrund har Foucault yderligere givet en række konkrete analyser af, hvordan den sociale magt organiserer sig i spatiale forhold - magtforholdenes modulering af kroppene ennem disciplinerende rumorganis gennem disciplinerende rumorganiseringer

anstalten, fængslet, fabrikken, skolen, osv.
For Patocka og Foucault er forestillingen om For Patocka og Foucault er forestillingen om
rummets tilbagekomst knyttet til to sider af opgøret med det nittende àrhundredes idealisme, der begge har udgangspunkt i de historiske og sociale forandringer, som for alvor bliver følelige omkring de sidste århundredskifte, nemlig fænomenologiens livsverdensnære saglighed og den nietzscheanske sprog- og magtkritik. I begge tilfælde er der tale on tænkemåder, der umiddelbart opprioriterer rumlige forhold, kroppens „her" snarere end eksistensen ,nu“, den historiske situation med dens konkrete distribution af institutionaliserede handlingsanvisninger og udfoldelsesmuligheder snarere end en historisk mening, der realiserer sig $i$ en proces. ${ }^{6}$ Denne orientering mod livsverdenen og kroppen, mod immanente former og konkete manente former findes en hel race dredes tænkning, har et klart familieskab med den
nye sensibilitet for rumlige konstruktioner, som preger kunsten $i$ dette århundrede.

Disse udviklinger kan tilsammen betragtes som indicier for en kulturel krise i tidsforestillingen, der kan knyttes til på den ene side en ændring $\mathrm{i}$ forståelsen af individet og dets forhold til sin omverden, som ikke længere på nogen overbevisende måde kan fastholdes som en først og fremmest tidslig (og tidsskabende) relation, og på den anden side opkomsten af mere komplekse og ugennemtrængelige sociale og fysiske rum.

\section{Tekstens form}

Den tiltagende opmærksomhed på rummet har bidraget til at sætte spørgsmålstegn ved den form-ontologiske argumentation, som hos Lessing - og mange andre - knytter den litterære og sproglige fremstilling til et temporelt perspektiv, dvs. privilegeringen af successionens "nacheinander" som det afgørende. Et af de mest konsekvente forsøg på at vende perspektivet rundt og insistere på tekstens grundlæggende rumlighed, er leveret af Gérard Genette.7 Først og fremmest anfører Genette, at man kun har talt ufuldstændigt om sproget, når man har beskæftiget sig med den syntagmatiske sides nacheinander, dvs. det aktuelle sproglige udsagns temporalisede diskus, eftersom man da overser den pardich iske sides nebeneinander, at overser den paralge diske sides neboneingrer, at kelte sprogige valg

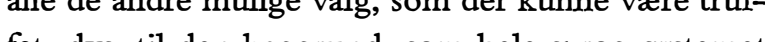
fet, dvs. til den baggrund, som hele sprog-systemet udgør, hvorved betydningsdannelsen sker i dette paradigmatiske nebeneinander. Denne logik gentager Genette dernæst på det enkelte værks niveau, idet værket kan siges at omfatte en lokal paradigmatik, som aktualiseres på forskellige måder gennem vær- ket. Den litterære betydningsdannelse sker således ikke alene, siger Genette, gennem forløbet, men også i relationen mellem de stykkevis aktualiserede sproglige elementer og de underforståede paradigmatiske grupper, som de er taget fra. Denne rumliggørelse bliver endda eksplicit, siger Genette, i metaforen, eftersom metaforen netop lancerer to for, efterom metaforen netop lancerer to

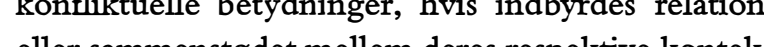
entekforlener det metaforiske udtryk med en mening.

Hos Genette er den litterære teksts rumlighed konciperet lige så formelt, som tidsligheden var det hos Lessing, dvs. som et af det sproglige mediums formtræk. Et andet forslag til at se en basal rumlighed $i$ teksten finder man hos Jurij Lotman, der tage udgangspunkt i tekstens semantiske organisering. Det litterære kunstværks semantik er, siger Lotman, karakteristisk ved at opbygge et individuelt netværk af relationer mellem betydningselementer - det, som vi forstår som værkets meningstukt Dise, som for relavis fositione, som Elisabeth Bronfen bemærker i forlængelse af Lotman, "betydningsrum . Med Lotman vil kontestationen af det Lessing'ske Jalta således have udgangspunkt i, at den litterære tekst ikke kun har et nødvendigt forlab, men også et univers, der implicerer et rumligt nebeneinander på samme måde som forløbet implicerer et temporelt nacheinander.

Tekstens betydningsrum er således kendetegnet ved, at det har en selvstændig, immanent struktur. Betydningsrummet er ikke blot et rum, som så at sige „hænger ved" de betydningselementer, som ak tualiseres i teksten; det produceres aktivt og fok-

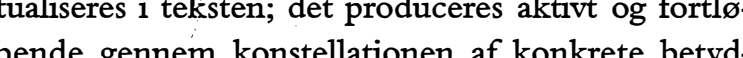
ningem , bemærker Lomn, „er mode for videns rum, og elementemes syntagmatik i teksten bliver et sprog for rumlig modeldannelse. 9 Den fortløbende strukturering af teksten bliver en fortløbende produktion a rumlighed, ikke en fremstilling af rum, men en produktion af relationer, som har en rumlig karakter. Betydningsdannelsen er uadskillelig fra en „,devenir- 
espace“, som Jacques Derrida har bemærket. Io $^{\mathrm{Be}}$ Be tydningsdannelsens rumgenererende strukturer kan genfindes på en række forskellige niveauer $i$ en tekst, fa den basie syntaks' system af rlationer til tekst, fra den basle syntaks system af relationer til mere komplicente den narrative kompositions system, de subjektive associationers systemer, de sociale relationers systemer, og så videre. Den "bliven-til-rum“" som kendetegner betydningsdannelsen, finder sted som en konsekvens af disse forskellige syntaktiske struktureringer og er for så vid et biprodukt af den semantiske organisering; den finder sted ,ved siden af" den primære betydningsdannelse. Men den har ikke desto mindre en egen konsistens; hvis ikke de rumdannende strukturer pà de forskellige syntaktiske niveauer $i$ teksten havde en grad af indre overensstemmelse, ville teksten formentlig kun vanskeligt give mening. Tekstens betydningsrum udgør således $i$ almindelighed et konsistensplan, med et af Gilles Deleuzes nytige sistensplan, ned et af cilles Deles begreber, et system af hver iser ner mellem beydningselementer, der tilsammen udgør en sammenhængende orden.

I det omfang man på denne måde kan tale om et "betydningsrum " $i$ en tekst og om at dette betydningsrum udgør et „konsistensplan“", er det imidlertid stadig kun på et overvejende formelt niveau. Men spørgsmålet om det litterære rum omfatter også et tilsvarende indholdsmæssigt niveau, nemlig den rum-anskuelse, som modsvarer det formelle betydningsrum. Før der kan redegøres for udvekslingen mellem tekstens betydningsrum og rumanskuelsen er det imidlertid nødvendigt at indskyde en principiel skitse of rumanskuelsens looik, hvilket her vil ske med udgangspunkt i den fænomenologiske ide om „det levede rum“.

III. Det levede rum

Enhver rumlig orden har udgangspunkt $i$ et system af relationer, $i$ overensstemmelse med Leibniz' berømte og lapidariske definition: „spatium est ordo coexistendi". Definitionen går igen hos Kant, som betragtede anskuelsen af rummet som association af nærværende elementer. Anskuelsen af rummet, ikke rummet som sådan; rummet som sådan findes ikke en kritisk filosofi som den kantianske. Rummets form er en apriorisk form - noget omfattende, kontinuert og deleligt - der går forud for enhver mulig anskuelse som dens betingelse. Men rummet viser sig kun $i$ anskuelsen, som trækker forbindelseslinie mellem anskuelsesgenstande. Ir Kant vover med andre ord itke, som Descartes og en hel trition on dage, at give en objekint-geomen defin af met; han begrænser sig til det, som viser sig for an skuelsen, dvs. ikke et kosmologisk rum, men et „subjektivt“ rum, anskuelsens ordnende etablering af forbindelser mellem sameksisterende genstande og sagsforhold.

Rumanskuelsen involverer set på denne måde groft sagt to elementære komponenter: på den en side hvilke sameksisterende genstande og sagsforhold, der udvælges og inddrages $i$ konstruktionen, og på den anden side hvilken type af relationer, der etableres, dvs. hvilke „regler“", der styrer associatio Eller med andre ord: hvordan elementer udnen. Eler med andre ord hordan elementer udvalges, og hvordan de sates sammen. Disse to funktioner, som gør det muligt at erfare og anskue fum tiserende aktivitet. Skemaet optræder hos Kant som en art billedmatrice eller strukturmønster for anskuelsen, som på den ene side forud-former de anskuelser, der dannes i perceptionen af verden, og på de anden side konkretiserer forstandens begreber, således at der dannes en forbindelse mellem sansning os forstand, hvilket overhovet er en betingelse for, at det er muligt at erfare den sansede verden. Disse skemmaer er imidlertid ikke, sådan som Kant nærmest synes at forudsætte, konstante; de indgår $i$ en foran derlig historisk erfaringshorisont som har to sider, der er nert sam der er nant saly enologisk

Skematismens kulturelle side er ikke mindst blevet understreget af Ernst Cassirer, som i en nykantiansk konciperet kulturhistorisk tænlming betragter skemabegrebet som en enestående invitation til at fastholde den historiske formning af den menneskelige erfaring, idet skematismen og dens før-begrebslige synteser, som Kant opstiller, netop kan betragtes som historiske modeller for orienteringen i og erkendelsen af en foranderlig omverden. Cassirers begreb om „symbolske former“ kan betragtes som et bidrag til at beskrive sådanne modeller, ikke som ideale forstandsformer, men som historisk konstruerede former. Den erfaring af verden, som udspille sig i udvekslingen mellem forta sig i udvekslingen merstandens begreber o den sansellge assire " hvor selektion principper og for for-begreb lige syntese af anskuelsens materiale hidrorer fra $\mathrm{d}$ til rådighed stående symbolske organisationsformer der kendetegner en given kulturel sammenhæn Med dette begreb om en kulturel erfaringskonteks fastholder Cassirer, at den kritiske analyse af bevidsthedens møde med verden altid må tage højde for bevidsthedens faktiske historiske situerethed. Den konkrete erfaring kan ikke beskrives med transcendentale funktioner alene; den er neddykke $i$ en kontekst af sedimenterede erfaringsformer, som kommer til udtryk i de skematiseringer, der er indskrevet $i$ historiske symbolske former. Fosto indrummet - udvelg rummet udvalgelsen af elemeringe f sanm ine heller ikke umiddelbar; den betjener sig af "sprog", af de overleverede skematiseringer, der muliggør anskuelsen.

Dette sprog er givet, men samtidig modificeres det bestandig gennem de forandringer, den menne kelige livsverden undergår. Derfor er der ofte en tendens til usamtidighed i rumanskuelsens ,sprog ", en latent konflikt mellem de overleverede skematiseringer og det foreliggende materiale. Rumanskuelsen indebærer dermed også en fortløbende forhandling mellem kulturelle former og det konkrete materiale, anskuelsen opererer med, mellem kulturel for-forståelse og empiriske muligheder.

Denne dobbelthed ligger også under den unge Heideggers eksistentielle fænomenologi, hvor rummet på den ene side altid er givet på forhånd som et kulturelt kompleks, som eksistensen er "kastet" i mens det på den anden side samtidig hedder, at rummet vokser frem af den subjektive omgang med en omverden, knyttet til specifikke, lokale muligheder i dette møde..$^{\text {I3 }}$ Dette rum, som er givet med den overleverede livsverdenen, er en eksistentiel horisont, en fortrolighedshorisont, som $\mathrm{i}$ den enkelt- menneskelige eksistens' perspektiv er absolut. Men samtidig, og det er den anden side af Heideggers analyse - den side, der for ham var den afgrende forholder individet sig ogs hondende og dermed ocsa transformerende til den det er sedi. I sin le det er stedti 1 sin kappe, stemmelse af livsverdenens rum i $\$ \$ \int_{23-24}$ af Sein und Zeit betjener Heidegger sig af tre ordbilleder. Den forste bestemmelse er rummet som „Ent-fernung", hvilket overhovedet er et møde med rumlighedens fænomen $i$ erfaringen af en afstand mellem et "dér" over for et "her", som skal knyttes sammen $i$ kraft af en faktisk eller projekteret besørgelse af et ærinde, hvis meningssammenhæng er givet med den eksistentielle subjektivitet. At forholde sig til dette rum er nu, med den anden bestemmelse, en „Begegnung", som i sit møde indtager rummet, gهr det til et sted" (Gegend) for den subjektive handlen disponerer det foh for den subje subjer Denteriale. Din "Ein-raumen ", pà den ene side en slags underkastelse under (eller indrømmelse til) den foreliggende verden, og på den anden side en indtagelse af rummet gennem en temporaliseret subjektiv handlen, hvormed rummet først viser sig.

Heidegger lægger som sagt selv afgørende vægt på dette sidste perspektiv, hvor rumlighed - ligesom temporalitet - er noget, der skabes i den subjektive eksistens' kosmogoniske gestus. Men samtidig indebærer den livsverdenfænomenologi, han tager udgangspunkt $i$, en indsigt $i$ rummets overlevering som neste ongang andyeres - a da historis form et histonisk fomidet, sam - mad Cassier - som et sprogligt-symbolske, institutionelle og fysiske - geografske, arkitekn fon en keltmenneskelige eksistens. Kombinationen af disse to perspektiver, rummet som overleveres $i$ historiske symbolske former og rummet som rum for den menneskelige livspraksis, udgør tilsammen hvad man kunne kalde „det levede rum". ${ }^{\text {I4 }}$ Rummet er knyttet til eksistensen som aktualiserer det, „lever det", $i$ en stadig oscillation mellem det givne og det skabte, som i realiteten ikke kan skilles ad, idet det 
givne altid aktualiserer sig $\mathrm{i}$ den skabende gestus, li- $\quad$ som udgør et vældig uoverskueligt, men spontant gesom skabelsen altid vil reproducere det givne, også hvor den $i$ det samme modificerer det. Samtidig kan man imidlertid forestille sig mange måder at konstruere dette levede rum på, afhængigt af forskellige menneskelige praksistyper $i$ indtagelaf forskellige menneskelige praksistyper i indtagel-
sen af den foreliggende livsverden, og måden, hvorpå disse praksistyper fokuserer på overleverede hvorpå disse praksistyper fokuserer på overleverede
anskuelsesmønstre og modificerer dem $\mathrm{i}$ handlinger. anskuelsesmønstre og modificerer dem i handlinger. Det afgørende er i denne sammenhæng, at den per-
spektivisme i rumkonstruktionen, som er givet med spektivisme i rumkonstruktionen, som er givet med
den kritiske filosofi, ikke afskaffer det fælles og $\mathrm{i}$ den kritiske filosofi, ikke afskaffer det fælles og $\mathrm{i}$
dagligdags forstand meningsfulde rum til fordel for dagligdags forstand meningsfulde rum til fordel for tilfældige idiosynkrasier. ${ }^{\mathrm{IS}}$ Blot findes der under den fælles meningsfuldhed en hel vifte af rumkonstrukmed dertil hørende mere eller mindre konventionelle associationsindhold, til de faktiske strategier, som det sociale rum phalnges og ibrugtages efter. Vi begriber ikk Vi begriber ike den a ninger mindre end dagano subway som representioner af nerne, som kan beslinves ud fra den kritiske erkendelsesteoris redegørelse for etablering, udvalg og sammenmontering af virkelighedsmomenter, er fælles, eller $i$ hvert fald begribelige som deviationer fra fælles kulturelle former. Geometrien, fænomenologien, psykopatologien og byplanlægningen - og vældig mange andre discipliner - bidrager alle til at begrebsliggøre en fælles, kulturel handlings- og erkendelsespraksis i konstruktionen af rum. Menneskelivet udfolder sig bestandig $i$ et overleveret rum, som det modificerer, og såvel overleveringen som modifikationen antager mange forkellige former, lise former, lige sà mange som der findes rum. Den skematisering, mane som der findes num. Den skebsiseetablering, udvalgelse og forbindelse af anskuelsesgenstande - er til stede som et tykt kulturelt lag af indsigter, vaner, handlingsmønstre, affektive mønstre, spontane organisationsmønstre, og så videre, som eksisterer side om side, uden at der findes en overordnet, privilegeret indfaldsvinkel til dem. Disse problemstillingers indbyrdes orden og sammenvirke aftegner et kompleks, som betragtet under ét er en kulturs rum, et kompleks af rumkonstruktioner, genkendeligt „hjemme“

IV. Det littercere rum

Dette kulturelle kompleks er altid til stede som en afgørende komponent i det litterære værks diskursive konstruktion; derfor har det litterase nur distinkte elementer: på den ene side det formelle betydningsrum, på den anden side rum-anskuelsen historisk-kulturelle skemata. Forholdet mellem de litterære betydningsrum et medie for den historiske rumanskuelse, og på den anden side er det litterære betydningsrum en model for konstruktionen af anskuelsens rum. Betydningsrummet er et medie i det omfang det kommunikerer en anskuelse og anskuelsens præmisser, men det er samtidig en model i det omfang det ikke blot betegner anskuelsen, men yderligere konstruerer den i faktiske, eksplicitte forensplicte forSom medie er teksten privilegeret, efte

Sorsom den kan konstruere et komplekst netværk af relationer, det levede rum. Det levede rum lader sig ikke reducere til en geometrisk eller matematisk konstruktion, derfor må en repræsentation af det rekonstruere relationer på en lang.række forskellige niveauer, sansemæssige, emotionelle, kognitive, handlingsmæssige, osv., ydre og indre impulser mellem hinanden, evidente såvel som idiosynkratiske. Maurice vende erfaring af det levede rum, dvs. på at anskuelsen af rummet ( $\mathrm{g}$ af menneskets omverden overhovedet) altid har en unik signatur, en unik toven kerlitin litet $i$ teksten. "Med udgangspunkt i en erfaring, de kan være nok sa banal, men som for forfatteren tilhører livet med en ganske bestemt smag, og vider derne, en syntaks, ja, selv de litterære genrer, måder at fortælle på, som allerede gennem deres brug er mættet med et fælles betydningsindhold, som alle kan betjene sig af - med dette dobbelte udgangsto elementer er komplekst; på den ene side er det in spektrum af muligheder, som som modsvarer kompleksiteten i konstruktionen a Merleau-Ponty, som altid har insisteret på den lemed udgangspunkt $i$ ordene, formerne, talemà- punkt skal forfatteren udvælge, sammensætte, behandle og mishandle disse instrumenter, således at de fremkalder den samme livsfølelse, som er i forfatteren, men nu udfoldet $i$ en imaginær verden og

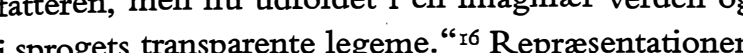
i sprogets transparente legeme. "Repræsentationen af det leve $i$ ningsrm i tel levede rums specifciket Nar Melean-Ponty ligner tekste med et legeme, ${ }^{\mathrm{I} 7}$ fastholder han dels betydningsrummets karakter af en kompliceret afstemt totalitet, og introducerer dels en forestilling om en homologi mellem den umiddelbare erfaring af verden, som er kropslig og syntetisk, og denne erfarings sproglige objektivering som en art transsubstantiation, en overførsel af kroppens berørthed til sprogets legeme, som er transparent og fremviser alle associationer, sammenhænge og tværforbindelser pà sin overflade. Kroppens mangeartede reaktioner og impulser $i$ en given situation motoriske, sanselige impulser i en psykologisk, beskrive i her singens, perceptionspsykologiens, drommetydningens, epistemologiens forstaelsesformer - som skyder sig sammen $i$ en anskuelse, kan alle realiseres uden videre tekstens rene overflade; den kan forbinde et hus med en glæde eller en flod med en sorg uden af den grund at skulle forklare noget: den udgrunder hverken kroppens situation eller sindets tilstand, men konstruerer anskuelsens og sansningens objektivitet dens diagram af elementer, momenter og værdier.

Litteraturens rum aftegner sig $i$ en bevægelse frem og tilbage mellem erfaringens og anskuelsens rum på den ene side og tekstens betydningsrum på de anden, mellem den situerede erfaring af verden anden, mellen of (re) inct som ka (re)konstruere sansningens komplekse rum. Ingen a de to kan for sig gore rede for telstens rum; erfaringens rum er flygtigt, og der findes ikke nogen umiddelbar màde at aabilde dets objektivitet på, de kalder på tekstens (re)konstruktion, på teksten som model. Og omvendt bliver tekstens betydningsrum taget for sig et billede uden ret mening, hvis ikke det forstås som medium for en rumlighed, for fremstilling af anskuelsens rum. De to sider virker sammen, teksten kan kun repræsentere et rum ved at konstruere et system af relationer, der modsvarer det levede rums konstruktion af anskuelsen, og teksten kan kun konstruere et rum $i$ dens egne indre system af relationer, hvis dette rum forstås som en objektiveret anskuelse. Man kunne sammenfatte denne dobbelthed ved at bestemme teksten som et anskuelsesmedium, hvor levede rum kan fastholdes, og hvor mulige rumanskuelser kan konstrueres og undersøges.

Hvis en tekst ikke nødvendigvis er et specielt egnet medium til at optegne rummets fysiske udstrækning og bestemmelser - entreprenøren ville foretrække en tegning, geodæten et foto - kan den til gengæld bedre end de fleste andre fastholde sammenhængen $i$ det levede rum, og dermed altså netop den konkretion i erfaringen af det enkelte rum, som gør det til et menneskeligt rum. Litteraturens privilegerede adgang til rummet skyldes forst og fremmest dens mulighed for at fastholde det levede rum i hele dets mulighed for at fastholde det levede rum i hele des sam gen mellen handings, stemnings- og anskuelsessance sansning. Der findes talløse konstruktionsprincipper, mader at drage forbindelseslinierne i rumfremstillingen på. Der findes idiosynkratiske spillere og idiosynkratiske spilleregler $\mathrm{i}$ enhver fremstillling, som forhindrer os $i$ at skelne klart mellem tektonik og affektivitet; Dronningens audiensgemak er tektonisk gennemtrukket med tegn for den respekt, der må betrædes med, og kan næppe beskrives tektonisk uden at medtænke affekten; og Frédéric Moreaus affekt er formentlig det vigtigste tektoniske element i begribelsen af det første horehus, han betræder. Tektonikken er social og affektiv, til og med idiosynkratisk: det hele indgår $i$ et historisk kontinum. Man kan naturligvis analytisk sondre mellem det overvejende geometriske, de sociale og historiske koder, det rummer, og den reaktion, som det afstedkommer $i$ en krop og et sind, mellem extensa og cogitans, men det er en hjælpekonstruktion uden særlig sanktion i det virkelige.

Litteraturen foretager en skematisering af rummet gennem udvælgelse og etablering af anskuelseselementer pa den ene side og om konstruktion af forbindelser på kryds og tværs mellem dem på den an- 
den. Som medie giver den os adgang til det historiske London, Dickens' romaner udspiller sig i, eller det historiske Petersborg, Bely fremstiller. Men den omfatter også skematiserende greb i modelagtig forstand, som vadrer, hvord dete historise rom stand, som vedrarer, houdan dette historiske rum ses, hvordan typer reflekterende indfald udformes $i$ og med dette rum, hvordan f.eks. kulde hos Dickens formindsker rummet $\mathrm{i}$ frysende indadvendthed, mens den hos Bely udvider det i glasagtig sprødhed. Det så at sige objektivt udmålte rum lejrer sig $i$ et levet rum, Dickens' frysende London under Napoleonskrigene, Virginia Woolf vibrerende London, fuld af tilblivende betydning, Rushdies multikulturelle London, rig på utænkelige sammenstød og utænkte indsigter. Der findes ikke en repræsentation af et levet rum, som ikke også opfinder et rum; det er repræsentationens opgave at fastholde det særlige $i$ ethvert rum den livets sma $^{\prime} i$ et s. hvert rum, den livets ,smag $i$ et givent rum, som Merleat der on, on betegnes, men ma konsto overleverede, til radighed staende udtryksmidler, en "kohærent deformation" af udtrykkets materiale.$^{8}$ Den litterære skematisering af rummet bevæger sig på denne måde hele tiden på kanten mellem at være medium for et repræsenteret rum til at være model for et virtuelt rum, mellem det kendte rum og det usete, som realiseres på de kendte præmisser, hvad enten det usete er det synlige London eller det er et naturteater i Oklahoma. Overgangen fra det reprasenterede til det virtuelle - man kan her på nogenlunde samme måde tale om Isers "fiktive" eller om Todorovs fantastiske" "rg - sker da ikke simpelt hen ved, at nogle kendte principper for rumgestalting udfyldes med element, somilke bon forhond kendt og meningfild sangenteng,

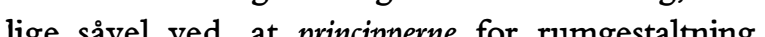
lige savel ved, at principperne for rumgestaltning, ikke elementerne, men reglerne, forandres, så rummet i Musils Østrig meget vel kan være betydelig mere fremmedartet end rummet i Orwells Oceanien. ${ }^{20}$

V. Litteraturen og opdagelsen af det menneskelige rum Det levede rum er per definition ikke „objektivt“ i empirisk forstand som et cartesiansk res extensa.
Men det betyder på den anden side ikke, at det er „blot" subjektivt; det levede rum har en objektiv tektonik, konstruktionen af en anskuelse, der blot kan forekomme kompliceret, idet den fusionere aspeker af kulturle ansulsesum, pragmatise spekter af kulturelle anskuelsesrum, pragma dingsrum og idiosynkratiske stemningsrum. Den litterære skematisering af rummet-objektiveer et levet rum - eller „,eveligt“ rum, dvs. et rum anskuet på den levede erfarings niveau $-i$ et system af relationer. Denne skematisering er en konstruktion af rummet som en imaginær anskuelse. Anskuelsen er ikke et "færdigt" billede, men udgør et, som Sartre sagde, ,tyndhåret billede“", der forholder sig til anskuelsen af et virkeligt levet rum som et kort til et territorium - den givne skematisering angiver nogle bestemte elementer og relationer, som den læsende fantasi derefter må forestille sig rummet ud fra, ikke blot topografiske, men også affekive osv. som kan fyldes yderligere ud inden for disse rammer.2 R ive “" garc gennem en skematiserende angivelse af hvilke momenter, der indgår $i$ konstruktionen af rummet, og hvilke forbindelser, der skal eksistere mellem dem. Den skematiserende konstruktion fremstiller et billede af verden, ikke blot ved at henvise til virkelige eller imaginært forståelige genstande og komplekser osv., men i kraft af det litterære betydningsrums syntaks, de formelle og semantiske regler for sammensætningen af elementer. Heraf kommer litteraturen særlige forhöld til rummet, dens , ontologiske" " nærhed, om man vil, til fremstillingen af rum. Og heraf hed, Om litterat, in fret kommer rumlighed tike allerde ekiste ailsvarende kendte stemningsregistre og handlingsperspektiver, men som så at sige sætter imaginationen på nye opgaver og dermed - naturligvis - føje endnu ikke gjorte indsigter til vores livsverden. Litteraturen er en imaginativ praksis, hvis måder at konstruere relationer i rum lærer os at se rummet omkring os.

Men overalt, hvor der på denne måde er tale om et litterært rum, er der omvendt kun meget sjælden tale om et egentlig „,beskrevet“, direkte repræsenteret rum. Rummet er i almindelighed først og fremmest impliceret i de forekomster af handling, sansning, tænkning og følelse, som udfoldes i teksten. Rum-beskrivelsen er blandt de mindst betydningsRum-beshols or fotydningsfulde mader at frem litterære alt det, som ellens afdryer sig i telsten, hvilket formentlig er en af grundene til, at der for det meste har været tendens til at betragte rummet som noget sekundært, en nødvendig og mere eller mindre nødtrrftig ramme for de afgørende handlinger osv. Disse to ting har imidlertid ikke noget med hinanden at gøre; rummets betydning for det litterære billede og den litterære erfaring har ingen relation til omfanget af det beskrevne rum i en tekst - det e præcis dette forhold, Bakhtin understregede med sit originale begreb om kronotopen og tekstens kronotopiske karakter.22

Anskuelsen af rummet er til stede som horisont for en tekst i kraft af de konstruktionsprincipper, den ikke udfører, men forudsætter; den er til stede i tekstens aktualisering af bestemte rumkonstruktioner dvs. i repræsentationen eller „semiotiseringen“" af givne rum, hvilket aldrig blot er en benævnelse af en referent, men konstruktionen af den kulturelle verdens fiber; og den er til stede som den ressource, der mobiliseres $i$ tekstens overskridelse af den umiddelbare repræsentation, i konstruktionen af fiktive rum. ${ }^{23}$ Det kræver forskelligartede og hver for sis specifikke kompetencer at forstå Dantes rum, Cervantes' rum, Stendhals rum og Joyces rum; hvert tilfælde forudsættes en række principper associationsregler - den vertikale kontinuitet i i antes rum den hoison tes rum, den horis dervantes' rum, den geo-poliske rigidiet i Stendhals rum, ncipper modsvarer bestemte dominerende organisationsformer forstålelsen af rummet, verdensbygningens rum, vejenes og det åbne lands rum, nationalstatens rum og byens rum, som hver især aktualiseres og fremstille i forskellige gennemløb med fire distinkte typer af vandrende helte. Og med optegningen af disse karakteristiske rum bliver det da endelig muligt at identificere og konstruere bestemte lokaliteter, der muliggøres i disse forskellig regimer, som kulturelt betydningsfulde; tarkslerne $\mathrm{i}$ Dantes univers, moderne hos Cervantes, stedets drommende mattethed hos Stendhal, transparisen i Joyces rum, der bestandig kan rekonfigureres og dyellem tinkte steder og virkelighedsudsnit.

Skematiseringen af rummet i den litterære tekst, konstruktionen af associationsdiagrammer, som har udgangspunkt i et historisk rum og som modsvarer aspekter af det levede rum - af faktisk levede rum såvel som af blot virtuelle rum - er formentlig en af litteraturens vigtigste ressourcer $i$ dens evne til at fascinere, til at engagere den menneskelige indbildningskraft. Den litterære skematisering af rumanskuelsen er en erfaringsdannelse; konstruktionen af det litterære rum er en fortolkning af et virkelighedsspektrum, af elementer $i$ en livsverdens-kontekst, der fortolkes og gøres til et meningsfiuld ensemble som et rum for meneskelig handlen, for semble som affelt, for et ilsion har udgangsp det rækker videre end til at redegøre for dem; konstruktionen af det litterare num udfolder et billede, en forståelsesform, en måde at give mening til det foreliggende som et menneskeligt rum. De skematiseringer, som kræves til dette formål, er ikke nødvendigvis fikserede på forhånd, immanente $\mathrm{i}$ livsverdenen. Udfoldelsen af det litterære rum kan fastholde dem $\mathrm{i}$ deres provisoriske flygtighed, og kan dermed demonstrere, hvordan en kultur har givet mening og fasthed til sit rum, og den kan bidrage til at opfinde måder at konstituere rum på $i$ livsverdenens perspektiv. Hvor den i forste henseende udfolder og noterer en oplevelse of rum gen-

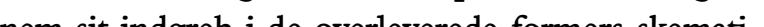
seringer, kan den $i$ anden henseende fungere som en art kulturelt laboratorium, et bidrag til konstruktionen af skematiseringer af det levede rum. I denne forstand er den litterære formalisering af rumlige skemaer en primær erfaringsproces, dels som en eksplicitering af en flygtig praksis, stemning eller indskydelse, som en kulturel horisont har muliggort, dels som en eksperimentel afsøgning af en vifte forskellige, virtuelle skematiserende modeller. I begge tilfælde optræder den litterære tekst som et 
erfarings-organ, som en produktion af sansninger og anskuelser, der modsvarer udfordringen fra en given livsverden, en given organisering af menneskelivets rammer. Litteraturen har i denne henseende en kulturel funktion som et laboratorium for menneskeligt en mønstergyldig konsom en effin struktionsproces - et varksted for skematiserend anskuelse - hvor implicitte rumskemata bearbejde og udmøntes $i$ aktuelle sansninger, der angiver måder at konstruere et levet rum pa, som har udgangspunkt $\mathrm{i}$, men samtidig rækker ud over den givne livsverdens horisont

\section{Noter}

r. Denne indvending er blevet rejst af Tom Mitchell, der anholder det som en simpel kategorifejittagelse, når Lessing slutter fra det formelle til det stoflige område.

2. Til spørgsmålet om $60^{\prime}$ ernes koncept- og go'ernes koneksstkunst, se Peter Weibel. KontextKunst, Wien 1995. T1 se Michel Foucault: Ceci n'est pas une pipe, Montpellier 1986, og min „Fornuftens kvartstoner", in Forslund \& Gassilewski (red.): Seans, Norrköping 1993.

3. Optrykt i essaysamlingen The Widening Gyre, New Brunswick 1963. En stor del af den debat, som Franks artikel har afstedkommet, er behandlet af W.J.T. Mitchell artiklen "Spatial Form in Literature: Toward a General cago 1980 .
coll (ed.). The Language of Images, Chr4. Frank

4. Frank tager her udgangspunkt i (en ganske håndfast und Einfühlung, og tager tendensen til en ,rummets genkomst" i l litteraturen til indtægt for en generel antihistorisme, et mytologiserende opgor med en historisk fremskridtsforestilling - en position, som formentlig er ganske dækkende for en del af det ideologiske fundament for nykritikken og dele af det tyvende arhundredes æstetiske modemitetskritik, jf. hertil Robert Weimann: „New Cn Halle I 962 , spec kap. I og 4 .

noble I988, ssrligt essayet , q'espace et sa pronologie, Gre6. Foucaults diskussion af rummet dukker op mange forskellige steder, tydeligt f.eks. i del II af Les mots et les choses, Paris 1966, i foredraget "Des espaces autres" fra I967, optrykt i Dits et écrits, Paris 1994, bd. 4, s. 752 , og i artik-
len „Nietzsche, la généalogie, l'histoire“, smst. bd. 2, s. ז36.
7. Se Gérard Genette: „La littérature et l'espace“, in Figures II, Paris 1969 . Genettes beskzftigelse med det litterære rum mà nok, i forfatterskabets sammenhæng, betragtes som et forholdsvis enkteltstaende eksperiment, hvor ha uden at interessere sig sorligt for konsekvenser og perlistik

8. Elisabeth Bronfen: Das literarische Raum, Tübingen I986, s. 353 .

ז973, s. 328.

Io. Jacques Derrida: Positions, Paris 1971, s. 39 .

II. Kant opridser i Kritik der reinen Vermunft en imponerende rundgang, stiliseret: for at kunne tænke og anskue en genstand, må vi nodvendigvis forudsætte rummet som apriori, dernest en genstand R - forst er der et rum for anskuelsen fortsetter da denne kede, som associntion af foreliggende genstande. Fra den aprioriske rumlighed til det anskuede rum er indført en genstand, som er fo udsat af det forste og forudsetter det andet. Se hertil min ")Topofili - om erfaringsformer og rumkonstruktioner kritisk og æstetisk belysning", in Bek, L. m.fl. (red.): Per spektiv pã rum. Det perspektiviske rum og dets alternativer so Kobenhavn 1999, i.p.

Philosophie der symbolischen Formen, bd. 3, s. $x 88$. 13. Se udfoldelsen af denne figur $i$ Martin Heidegger: Sein und Zeit, Tübingen 1967 (1927), s. III.

I4. Vendingen „das gelebte Raum" kommer fra Elisabeth Ströker: Philosophische Untersuchungen zum Raum, Frankfurt/M I965, idet hun her vil sammenfatte den rumbetragtning, der har udgangspunkt $t$ en fanomenologisk forståelse, til forskel fra det matematiske rums konstruerede

Is. Cassirer formulerer eksistensen af det $i$ erkendelseskri-

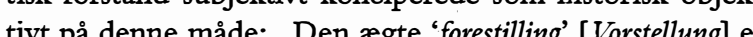
altid tillige en 'stillen-overfor' [Gegenüber-Stellung]; den udgår fra jeget og udfoldes ud fra jegets skabende krefter; men den erkender $i$ det samme en egen væren $i$ det således skabte, et eget væsen og en egen lovmæssighed - forestillingen lader denne væren opstå af jeget, men lader den bestå i overensstemmelse med dens egen lovmæessighed og anskuer den $i$ denne objektive tilstand.“, ,Mythischer, asthetischer und theoretischer Raum" (I930), in

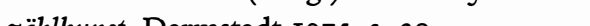

Donty: La prose du monde, Paris 1969 , sible et l'invisible, hvor der er tale om „,yylligheden (...) som bevæeger sig over $i$ en anden krop, som er lettere og mere transparent, som om den skiftede kød, forlod kroppens kød til fordel for sprogets", Paris 1964, s. 200. 18. La prose du monde, S. I28. Denne begrebsbrug er bleve sproglige udtryks manglende evne til at indfange denne, og om kunstens arbejde med at fastholde det singulære gennem bearbejdning af det kunstneriske materiale, se Lectures d'enfance, Paris I99I, s. 40 ff. furt 1991, s. $388 \mathrm{ff}$, og Tzvetan Todorov: Introduction à la littérature fantastique, Paris 1970 , s. 29. udviklet af Melleaus elev, Jean-Fançois Lyotard, som disrg. Se Wolfgang Iser: Das Fiktive und das Imaginäre, Frank-

20. Se hertil min "Byens kronotop“, in Barlyng m.t. (red.): Den littercere opfindelse af byen, Kobenhavn 1999, i.p. 21. Begrebsbrugen "territorium "vs. ,kort" optrader hos We se op.cil., s. 426-30.

mes du tique et theorie du roman, oversat til fransk af Daria Olivier, Paris 1978, s. 237, samt min „Byens kronotop“, in Barlyng m.fl. (red.): Den litterare opfindelse af byen, Kobenhavn 1999, i.p.

23.Jf. hertil Roman Ingarden: Das literarische Kunstwerk, Tübingen I965 (I93I), \$\$33-34.

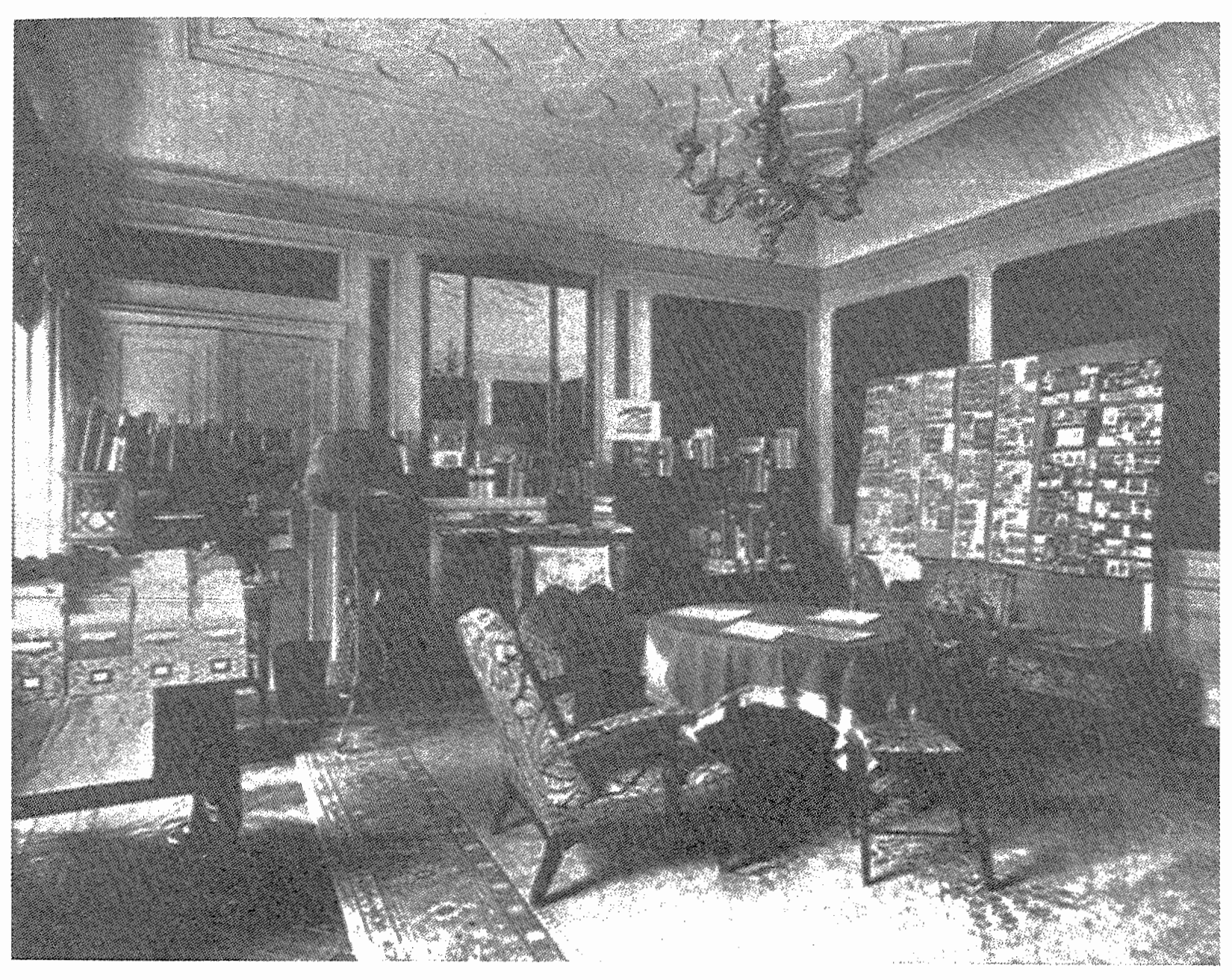

Aby Warburgs hotelvverelse i Rom, vinteren I928-29. 